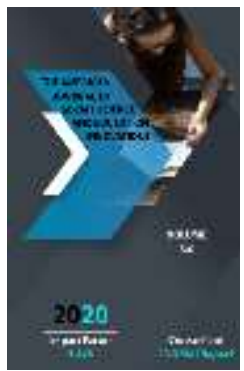

\title{
Methodology, Importance And Scientific Approach To Teaching Programming At School
}

\author{
Komilov Dilshodbek Komilovich \\ Specialised Boarding School Of The Ministry Of Internal Affairs Of The Republic Of \\ Uzbekistan
}

Journal Website: http://usajournalshub.c om/index,php/tajssei

Copyright: Original content from this work may be used under the terms of the creative commons attributes 4.0 licence.

\section{ABSTRACT}

This article provides information about teaching programming at school, the importance of teaching programming from school age, teaching methods and scientific approaches of specialists in this area, the innovations made.

\section{KEYWORDS}

Computer science, programming, online services, Kodable, Code Monkey, Code.org, Labyrinth program "Vim Adventures", Lightbot, Cargo-Bot, Scratch, SeeBot, C ++ programming language, "One million programmers" project.

\section{INTRODUCTION}

The purpose of the course "Fundamentals of Informatics and Computer Engineering" in general secondary education is to provide students with a thorough knowledge of information processing technologies and processes of their use, the ability to use computers wisely in educational and subsequent activities. and the transfer of skills, on the basis of which to form an idea of the contribution of new information technologies to the development of our country. Where there is progress and development, programming languages do not stop developing. Today, the form, structure and 
principles of data representation are completely different from the previous ones, new programming languages with very rich capabilities have been formed and are developing due to new versions that have a number of advantages over the previous ones. In return, there are a number of problems with teaching programming languages.

\section{MATERIALS AND METHODS}

Firstly, the disciplines of "Computer Science", "Fundamentals of Programming", "Computer Science Teaching Methods" are accelerating changes in the field of information technology, the expansion of computer capabilities, new operating systems and programming languages, information processing processes, networking. does not have time to register with. In the period leading up to the selection of a language, the definition of basic concepts and content for its teaching, the creation of teaching aids, the development of teaching methods and their implementation in practice, new versions or possibilities of these languages will be richer. New programming languages are being developed.

Secondly, there is no satisfactory answer to the problem of choosing programming languages for teaching among computer science teachers and identifying high-performance guidelines for teaching them. Once new programming languages are created, the main obstacle is, of course, the lack of importance of teaching the "old" ones.

Thirdly, the paradigms of teaching computer science are changing. While 20-30 years ago the concept of computer literacy was based only on programming languages, now the general cultural and professional aspects of computer science are becoming more important. This, in turn, requires reconsidering and constantly enriching the issue of teaching programming technologies in educational institutions. Therefore, today the main issue is the teaching of programming from school age and its importance. At the same time, the state is trying to create the necessary conditions and facilities for teachers' scientific approaches. It should be noted that the laws issued by the President in 2020 also contain provisions on the development of programming and quality organization of programming in schools.

So, programming needs to be taught from the age when the child's brain is young and free to receive information. Because programming develops logical thinking and the ability to plan one's actions. For this reason, a number of educators and technology specialists have developed methods for teaching programming at school, as well as a number of game-based programming programs.

\section{RESULT AND DICUSSION}

The age of the following recommended games is not so limited and can be played by both a two-year-old boy and a schoolboy, as well as a basic knowledge of programming:

1. Kodable is a great online service for elementary programming education. It is useful for both teachers and parents who teach online. The authors of the project claim that the game can be played even by two-year-old children. So with Kodable, kids learn programming before they can read and write. The design is bright and cheerful. The child plays in mazes with cheerful "hundreds" and learns the science of programming in parallel. All tips are presented in the form of pictures, not in the form of complex instructions. Even the smallest participant will quickly understand this. This program is an ideal tool for computer science in elementary school. Both teachers and parents can monitor the progress of the game. It can be used to determine the level of complexity. 
2. Code Monkey. This game offers a real programming language (CoffeeScript) that allows children to write their own games in HTML5. It does not require basic experience: education starts from scratch. The basics of computer science are mastered through the adventures of a unique cheerful game hero. The level editor allows you to change the look of the game independently. This game is especially useful in elementary school. The antique monkey takes students through a series of stages, and the child develops coding skills. As well as learning programming, the child will spend time in front of the computer efficiently and joyfully. Most importantly, stay away from useless computer games.

3. Code.org. The convenience of this service is that you can choose the language you understand before starting the game. For children like Kodable, there are sections for teachers, as well as the opportunity to create a personal game. The child learns programming and understands the basics of algorithms. When one of the tasks is completed, the child is given a certificate as a bonus.

4. Vim Adventures. Labyrinth Vim Adventures helps you learn Vim in a game format. Many of the characters give instructions on what to do at this or that stage, as well as develop some useful initial skills when working with Vim. This puzzle is getting more and more complicated. Very useful game. The only "minus" is that it is in English: the words of the protagonists have to be translated either by the child himself (on the one hand, it is an incentive to learn the language) or to help students understand and play the game. the help of an anteater will be needed.

5. Lightbot. This game is also in English, but it is worth recommending. The game can also be downloaded to a tablet or smartphone. The protagonist is a dwarf robot. He will carry out the actions assigned to him under the specified conditions. He goes from one place to another and turns on the lights in the designated places. The conditions are simple, but the skills gained from this are very useful for the child. The application is recommended for both school-age children and preschool children (4-6 years). There is also a more difficult interpretation for older children (9-10 years old). The game is so fun that even adults like it. Lightbot develops logical thinking and problem-solving algorithms.

6. Cargo-Bot. Even kindergarten children can understand the basics. There is almost no text, so it is not difficult for young children to understand the tasks. The game gets more and more complicated. It develops logical thinking and helps build programming databases.

7. Scratch. The most popular project designed specifically for children. The child quickly learns to program through this game. It's not really a game, it's a complete coding tutorial. But its attractive design and fun conditions make it appealing to children. Scratch covers a wide audience, but it is more suitable for children over 8 years old.

8. SeeBot. A game close to the $\mathrm{C}_{++}$ programming language. Although the graphics of this game, which was created a few years ago, are a bit poor, this does not detract from its usefulness. SeeBot takes place on an alien planet, and its characters need to be coded to control it. Experts consider this game to be the beginning of Java, C ++ and C \# programming languages.

The President instructed to introduce the "One Million Programmers" project in computer science. At least 100 IT training centers will be opened in all regions, providing short-term 
training courses on the basics of programming, e-commerce and graphic design.

In the first phase of the One Million Programmers project, more than 62,000 students were covered and 5,400 of them were awarded certificates. The President instructed to improve the subject of "Computer Science", which is taught in the 5th grade, on the basis of modern technologies, to include in this science the directions of the project "One Million Programmers".

\section{CONCLUSION}

Today, the digital economy, the demand for egovernment services is growing day by day. However, currently only 185 of the 780 types of public services are available through the "electronic portal". In most organizations, the digitization of work processes is limited to the electronic document exchange. Therefore, it is necessary to hire programmers who have graduated through the e-learning program as IT specialists in government and business institutions. They will be responsible for converting all activities of organizations from traditional electronic to digital form. In addition, the President stressed the need to improve the IT infrastructure, increase the literacy of the population, especially young people.

The Ministry of Information Technology and Communications has been tasked with opening at least 100 digital technology training centers in all regions. These schools offer short-term courses in programming, ecommerce, and graphic design. Schools are being equipped with new technologies.

\section{REFERENCES}

1. Azamatov A.R. Fundamentals of algorithms and programming. Tashkent 2010.
2. Nematov A., Kulmuradov M., Tangirov A., Akbarova N. Basics of programming. Toshkent-2011y.

3. Ahmedov A., Taylokov N. Informatics. Tashkent, Uzbekistan. 2008 y.

4. B.J. Boltayev, A.R. Azamatov, A.D. Askarov, M.Q. Sodiqov, G.A. Azamatova. Fundamentals of Informatics and Computer Engineering 2011y.

5. Otakhanov NA On teaching objectoriented programming technologies. /I Problems of education. -Tashkent, 2008.

6. Roziyev R.A. , Yodgorov G.R., Mirsanov U.M. Delphi programming language to study Navoi 2012

7. http://websound.ru/. MIDI technology.

8. www.dastur.uz

9. www.ziyonet.uz 